\title{
Selenoxopropadienylidene (CCCSe) as a Bridging Ligand
}

\author{
Anthony F. Hill,* Richard A. Manzano, Manab Sharma and Jas S. Ward \\ Research School of Chemistry, The Australian National University, Canberra, ACT 0200, Australia.
}

\section{S Supporting Information}

\begin{abstract}
The reaction of $\left[\mathrm{W}\left(\equiv \mathrm{CC} \equiv \mathrm{CSiMe}_{3}\right)(\mathrm{CO})_{2}\left(\mathrm{Tp}^{*}\right)\right]\left(\mathrm{Tp}^{*}=\right.$ hydrotris $(3,5$-dimethylpyrazol-1yl)borate) with $\left[{ }^{\mathrm{n}} \mathrm{Bu}_{4} \mathrm{~N}\right] \mathrm{F}$ and selenium in the presence of $\left[\mathrm{RuCl}\left(\mathrm{PPh}_{3}\right)_{2}\left(\eta-\mathrm{C}_{5} \mathrm{H}_{5}\right)\right]$ affords a mixture of the tricarbido complex $\left[\mathrm{WRu}(\mu-\mathrm{CCC})(\mathrm{CO})_{2}\left(\mathrm{PPh}_{3}\right)_{2}\left(\eta-\mathrm{C}_{5} \mathrm{H}_{5}\right)(\mathrm{Tp} *)\right]$ and the selenoxopropadienylidene $\left(\mathrm{C}_{3} \mathrm{Se}\right)$ complex $\left[\mathrm{WRu}(\mu-\mathrm{CCCSe})(\mathrm{CO})_{2}\left(\mathrm{PPh}_{3}\right)_{2}\left(\eta-\mathrm{C}_{5} \mathrm{H}_{5}\right)\left(\mathrm{Tp} \mathrm{p}^{*}\right)\right]$, both of which were structurally characterised. The formation of the bimetallic $\mathrm{C}_{3} \mathrm{Se}$ complex is consistent with the intermediacy of the salt $\left[{ }^{n} \mathrm{Bu}_{4} \mathrm{~N}\right]$ $\left[\mathrm{W}(\equiv \mathrm{CC} \equiv \mathrm{CSe})(\mathrm{CO})_{2}\left(\mathrm{Tp}^{*}\right)\right]$ which could be observed spectroscopically and computationally interrogated, but not yet isolated.
\end{abstract}

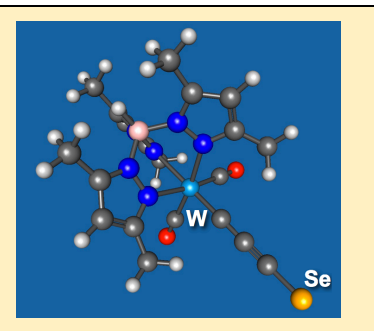

\section{INTRODUCTION}

Laser ablation of mixed carbon and selenium powders ${ }^{1}$ affords inter alia $\left[\mathrm{C}_{3} \mathrm{Se}\right]^{-}$, whilst the positive $\left[\mathrm{C}_{3} \mathrm{Se}\right]^{+}$ion has been identified via dissociative electron ionization of diphenyl diselenide. ${ }^{2}$ Neither conditions are applicable or attractive to condensed phase organometallic synthesis. Nevertheless, a consideration of the frontier molecular orbitals of the neutral molecule $\mathrm{CCCSe}^{3}$ presented in Figure 1 (alongside those for $\mathrm{C}_{3} \mathrm{O}$ and $\mathrm{C}_{3} \mathrm{~S}$, B3LYP/6$31 \mathrm{G}(\mathrm{d})$ ) suggest it to be a plausible ligand to bridge two metal centres.

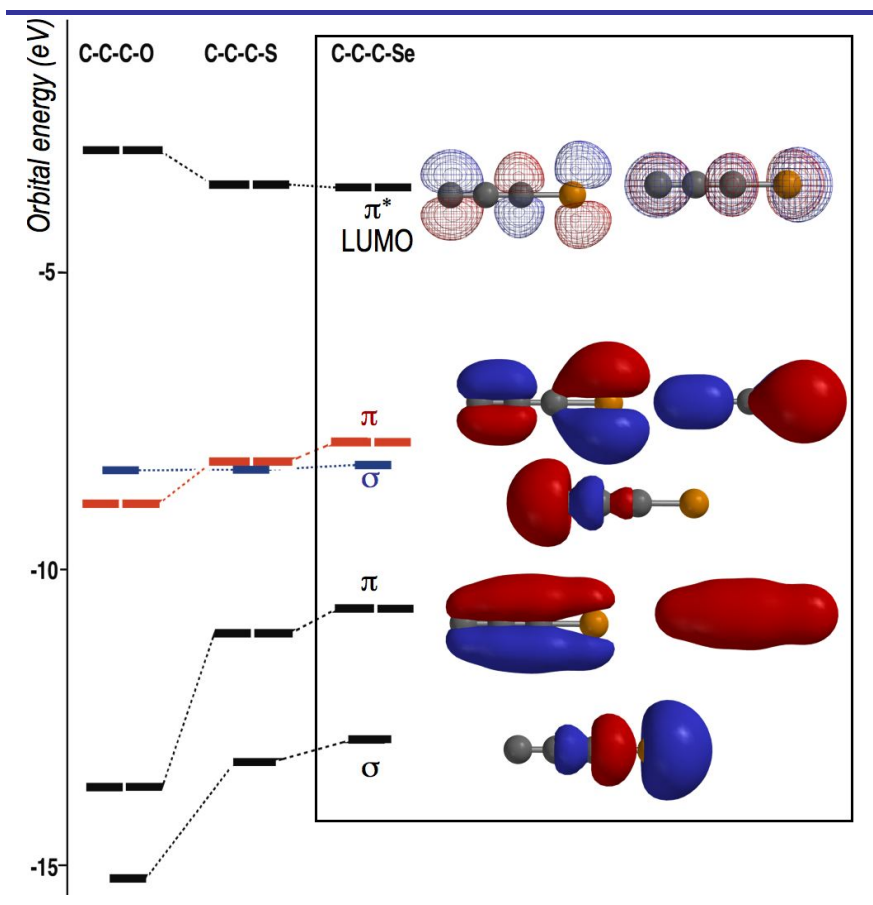

Figure 1. Frontier Orbitals for the Singlet CCCA $(A=O, S, S e)$ molecules.
Thus both termini of $\mathrm{C}_{3} \mathrm{Se}$ present orbitals suitable for synergic bonding to transition metals. Notably, in proceeding from $\mathrm{C}_{3} \mathrm{O}$ to $\mathrm{C}_{3} \mathrm{Se}$, whilst the $\sigma$-donor orbital is essentially unchanged, the energy of a degenerate pair of occupied $\pi$-orbitals increases (indicated in red, Fgure 1; reduced effective $\mathrm{p} \pi-\mathrm{p} \pi$ overlap on descending a $p$-block group) so as to assume the role of HOMO. Thus the tetra-atomic, when bridging two metals, should be capable of acting as a $\sigma$-donor, $\pi$-acceptor and $\pi$-donor ligand depending on the electronic requirements of the metal termini.

$\mathrm{We}^{4}$ and others ${ }^{5}$ have previously described the synthesis of alkynylselenolato complexes, $\mathrm{L}_{\mathrm{n}} \mathrm{M}-\mathrm{SeC} \equiv \mathrm{CR}$ which may be prepared via the reactions of lithium alkynylselenolates $\mathrm{LiSeC} \equiv \mathrm{CR}$. These are in turn prepared through the reaction of alkynyl lithium reagents with elemental selenium (Scheme 1).

\section{Scheme 1. Analogies Betwween Alkynylselenolate and} Isoselenocarbonyl Ligands.

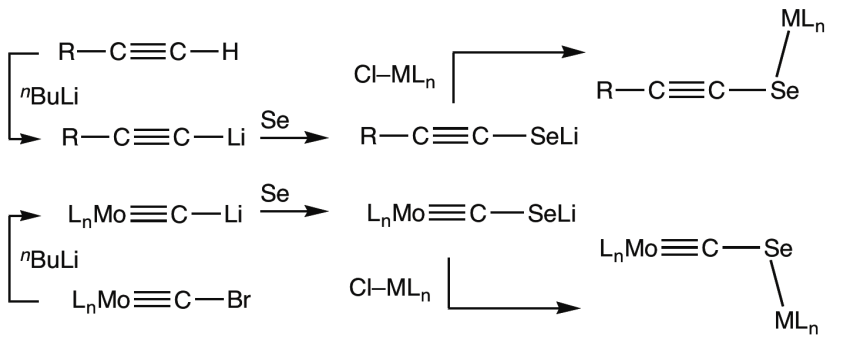

In a conceptually similar manner, we have also shown that the reaction of the lithiocarbyne $\left[\mathrm{Mo}\left\{\equiv \mathrm{CLi}(\mathrm{THF})_{\mathrm{n}}\right\}(\mathrm{CO})_{2}\left(\mathrm{Tp}^{*}\right)\right]\left(\mathrm{Tp}^{*}\right.$ $=$ hydrotris(3,5-dimethylpyrazol-1-yl)borate) with elemental selenium affords the selenocarbonyl salt $\mathrm{Li}\left[\mathrm{Mo}(\mathrm{CSe})(\mathrm{CO})_{2}\left(\mathrm{Tp}^{*}\right)\right]{ }^{6}$ the anion of which is a precursor to isoselenocarbonyl bridged bimetallic complexes. ${ }^{7}$ The only other synthetic route to such species involved the insertion of platinum into the $\mathrm{C}-\mathrm{Se}$ bond of an alkynylselenolatocarbyne. ${ }^{8}$ We have now successfully applied a similar strategy to the synthesis of the first complex of the $\mathrm{C}_{3}$ Se selenoxopropadienylidene ligand. 


\section{- RESULTS AND DISCUSSION}

The fluoride-mediated protodesilylation of silylpropargylidyne ligands provides a versatile method for the modular construction of tricarbido-bridged bimetallic complexes (Scheme 2). ${ }^{9,10}$ Prior to this the synthesis of tricarbido bridged bimetallic complexes was limited to Gladysz's application of the Fischer carbyne synthesis to lithiated metal alkynyls ${ }^{11}$ and a methylene-bis(carbyne) deprotonation/oxidation sequence described by Templeton. ${ }^{12}$ Thus treating $\left[\mathrm{W}\left(\equiv \mathrm{CC} \equiv \mathrm{CSiMe}_{3}\right)(\mathrm{CO})_{2}(\mathrm{~L})\right]\left(\mathrm{L}=\mathrm{Tp}^{*} \mathbf{1 a}, \mathrm{Tp} \mathbf{1 b} ; \mathrm{Tp}=\right.$ hydrotris(pyrazol-1-yl)borate) ${ }^{13}$ with $\left[{ }^{n} \mathrm{Bu}_{4} \mathrm{~N}\right] \mathrm{F}$ (TBAF) in the presence of a range of metal chloro complexes $\left(\mathrm{ClML}_{\mathrm{n}}\right)$ affords heterobimetallic tricarbido complexes $\left[\mathrm{W}\left(\equiv \mathrm{CC} \equiv \mathrm{CML}_{\mathrm{n}}\right)(\mathrm{CO})_{2}(\mathrm{~L})\right]$, implicating the intermediacy of the mononuclear tricarbido complexes $\left[\mathrm{W}(\equiv \mathrm{CC} \equiv \mathrm{C})(\mathrm{CO})_{2}(\mathrm{~L})\right]^{-}\left(\mathrm{L}=\mathrm{Tp}^{*}[\mathbf{2} \mathbf{a}]^{-}, \mathrm{Tp}[\mathbf{2} \mathbf{b}]^{-}\right)$. We therefore considered whether the intermediate anionic complexes [2] might be sufficiently nucleophilic as to react with elemental selenium in a manner akin to lithium alkynyls and lithiocarbynes (Scheme 1).

Treating a mixture of $\mathbf{1 a}$ and elemental grey selenium suspended in THF with TBAF provided a dark yellow solution accompanied by the disappearance of selenium. Attempts to isolate the intermediate salt, presumed to be $\left[{ }^{n} \mathrm{Bu}{ }_{4} \mathrm{~N}\right]\left[\mathrm{W}(\mathrm{CCCSe})(\mathrm{CO})_{2}\left(\mathrm{Tp}^{*}\right)\right]$ $\left(\left[{ }^{n} \mathrm{Bu}_{4} \mathrm{~N}\right][\mathbf{3 a}]\right)$ have not met with success, however limited spectroscopic data could be acquired in situ which are consistent with the formation of the desired species. Most notably, the infrared spectrum includes two $v_{\mathrm{CO}}$ absorptions (THF: 1898, $1833 \mathrm{~cm}^{-1}$ ) which may be compared with those for $\left[\mathrm{Mo}(\mathrm{CSe})(\mathrm{CO})_{2}\left(\mathrm{Tp}^{*}\right)\right]$ $(1908,1818),{ }^{6}\left[\mathrm{~W}(\equiv \mathrm{C})(\mathrm{CO})_{2}\left(\mathrm{Tp}^{*}\right)\right]^{-}(1916,1819 \mathrm{~cm}-1)^{15}$ and $\left[\mathrm{W}(\mathrm{CPPh})(\mathrm{CO})_{2}\left(\mathrm{Tp}^{*}\right)\right]^{-}\left(1889,1877,1771 \mathrm{~cm}^{-1}\right)^{16}$ suggesting that two resonance forms (Chart 1) contribute to the bonding description, one of which locates some negative charge on tungsten. A third mode is observed at $1973 \mathrm{~cm}^{-1}$ which we suggest corresponds primarily to a stretching mode for the WCCCSe spine.

Chart 1. Canonical Descriptions for (a) Alkynylselenolates and (b) Terminal CCCSe Ligands.

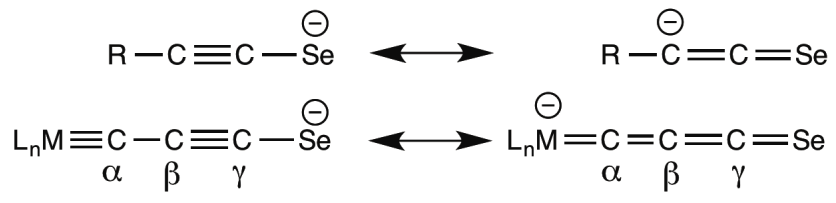

This is borne out by a computational study (BP86/6-31(d);SDD) which approximately reproduces the experimental infrared data (Scaled: 1945, $1808 v_{\mathrm{CO}}$ both coupled with $1996 \mathrm{~cm}^{-1} v_{\mathrm{C}-\mathrm{C}}$ ), notwithstanding the caveat of comparing theoretical gas-phase data for anionic species with those obtained experimentally from solution, where solvation, dielectric and ion-pairing effects are known to influence the intensity and frequency of carbonyl vibrational modes. The HOMO (Figure 2) and near degenerate HOMO-1 primarily involve selenium lone pair character. The HOMO-2 corresponds to WCO binding whilst the HOMO3/HOMO-4 pair (Figure 2) are both $\mathrm{WC} \alpha \mathrm{C} \beta \pi$-bonding $(\mathrm{C} \beta \mathrm{C} \gamma \pi-$ antibonding) in combination with a significant contribution from $\mathrm{C} \gamma \mathrm{Se} \pi$-bonding. Taken together these results indicate that selenium might be expected to show pronounced nucleophilic character. Natural bond order derived charges are consistent with the negative charge being shared by tungsten $(-0.66$, Table 1$)$ and selenium ($0.08)$. The $\mathrm{NBO}$ analysis also indicates that the $\mathrm{WC}$ bond comprises a $\sigma$-bond $(36 \% \mathrm{~W}(s p d), 64 \% \mathrm{C}(s p))$ straddled by four bonding interactions of $\mathrm{W}(d)-\mathrm{C}(p) \pi$-symmetry. Though these extend along the WCCCSe spine, the net WC bond order aggregates to 2.85 . The $\mathrm{C} \gamma \mathrm{Se}$ bond also comprises both $\sigma\left(40 \% \mathrm{Se}\left(s p^{2}\right)\right.$ and $\left.60 \% \mathrm{C}(s p)\right)$ and, as noted above, two $\mathrm{C} \gamma \mathrm{Se} \pi$-bonding interactions $(\mathrm{NBO}=$ 2.15). Thus the computational study indicates that both the canonical forms presented in Chart 1 are useful in describing the bonding along the WCCCSe spine.

Table 1. Charge Assignments for [3a $]^{-}$.

\begin{tabular}{lcc} 
Method & W & Se \\
Mulliken & 0.18 & -0.44 \\
NBO & -0.66 & -0.08 \\
Hirschfeld & 0.06 & -0.30 \\
\hline
\end{tabular}
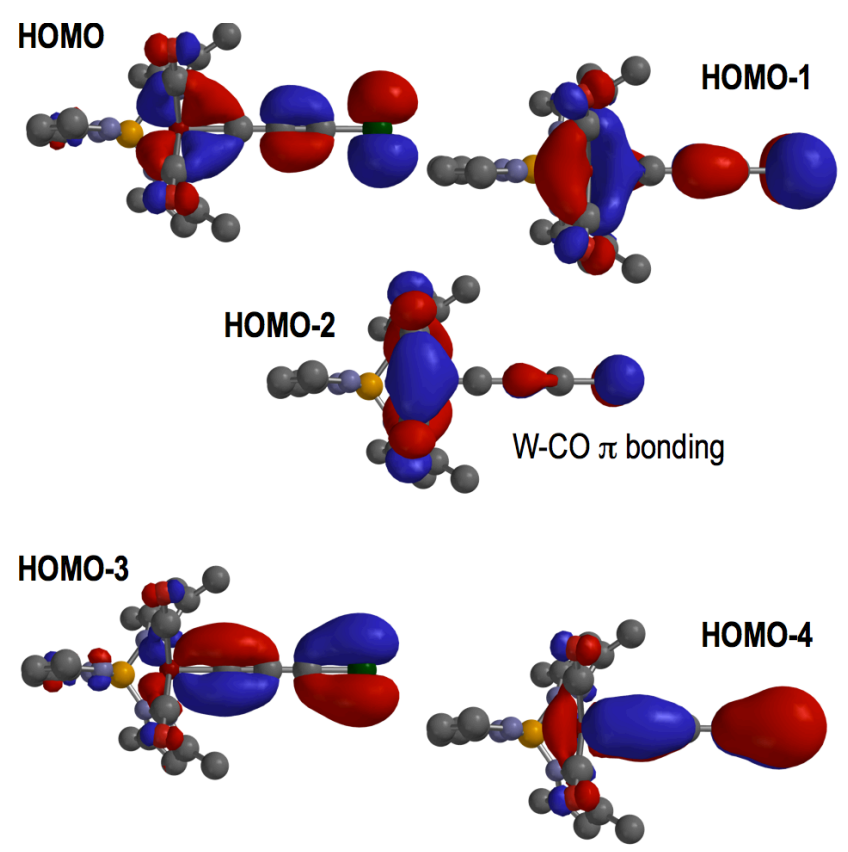

Figure 2. Computationally Optimized Geometry (Hydrogen atoms omitted) with Molecular Orbitals of interest (HOMO- $n, n=0-4$ ) for $[\mathbf{3 a}]^{-}$.

Given that the reaction of $\mathrm{LiSeC} \equiv \mathrm{CPh}$ with $\left[\mathrm{RuCl}\left(\mathrm{PPh}_{3}\right)_{2}(\eta-\right.$ $\left.\mathrm{C}_{5} \mathrm{H}_{5}\right)$ ] provides the alkynylselenolato complex $\left[\mathrm{Ru}(\mathrm{SeC} \equiv \mathrm{CPh})\left(\mathrm{PPh}_{3}\right)_{2}\left(\eta-\mathrm{C}_{5} \mathrm{H}_{5}\right)\right],{ }^{5 \mathrm{k}}$ we reasoned that a similar reaction might ensue with $[\mathbf{3 a}]^{-}$as a means of trapping this intermediate. This proved to be the case, although the yields were somewhat disappointing (vide infra). Following chromatographic

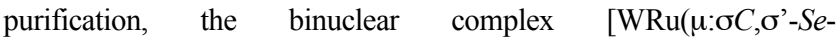
$\left.\mathrm{CCCSe})(\mathrm{CO})_{2}\left(\mathrm{PPh}_{3}\right)_{2}\left(\eta-\mathrm{C}_{5} \mathrm{H}_{5}\right)\left(\mathrm{Tp}^{*}\right)\right](4$, Scheme 2$)$ was isolated. The formulation of $\mathbf{4}$ follows from spectroscopic data and was confirmed by a crystallographic study, the results of which are summarised in Figure 3. The IR spectrum 4 included two $v_{\mathrm{CO}}$ absorptions $(\mathrm{KBr}$ : $\left.1973,1861 \mathrm{~cm}^{-1}\right)$ in a region typical of more conventional carbyne complexes of the form $\left[\mathrm{W}(\mathrm{CR})(\mathrm{CO})_{2}\left(\mathrm{Tp}^{*}\right)\right]^{17}$ in addition to a weak absorption $\left(\mathrm{KBr}: 1994 \mathrm{~cm}^{-1}\right)$ which is attributed to $v_{\mathrm{C} \equiv \mathrm{C}}$. The ${ }^{31} \mathrm{P}\left\{{ }^{1} \mathrm{H}\right\}$ NMR spectrum comprised a singlet $\left(\delta_{\mathrm{P}}=47.8\right)$ close to that observed for the corresponding alkynylselenolato complex 
$\left[\mathrm{Ru}(\mathrm{SeC} \equiv \mathrm{CPh})\left(\mathrm{PPh}_{3}\right)_{2}\left(\eta-\mathrm{C}_{5} \mathrm{H}_{5}\right)\right]\left(\delta_{\mathrm{P}}=42.5 \mathrm{ppm}\right) .{ }^{5 \mathrm{k}}$ The ${ }^{13} \mathrm{C}\left\{{ }^{1} \mathrm{H}\right\}$ NMR spectrum was however most informative due to the tricarbido unit being terminated by elements with spin-active nuclei $\left({ }^{183} \mathrm{~W},{ }^{77} \mathrm{Se},{ }^{31} \mathrm{P}\right)$, couplings to which allowed definitive assignment of the tungsten bound $\left(\delta_{\mathrm{C}}=252.7,{ }^{1} J_{\mathrm{WC}}=193.3\right)$, selenium bound $\left(\delta_{\mathrm{C}} 83.83,{ }^{3} J_{\mathrm{PC}}=10.6\right)$ and middle carbon $\left(\delta_{\mathrm{C}}=109.1,{ }^{2} J_{\mathrm{WC}}=55.9\right.$ $\mathrm{Hz})$.

Scheme 2. Synthesis of $\mu-C_{3}$ and $\mu-C_{3}$ Se Complexes. $\left(L_{n} W\right.$ $\left.=\left(T p^{*}\right)(C O)_{2} W ; \operatorname{RuL}_{n}=\operatorname{Ru}\left(\operatorname{PPh}_{3}\right)_{2}\left(\eta-C_{5} H_{5}\right)\right)$

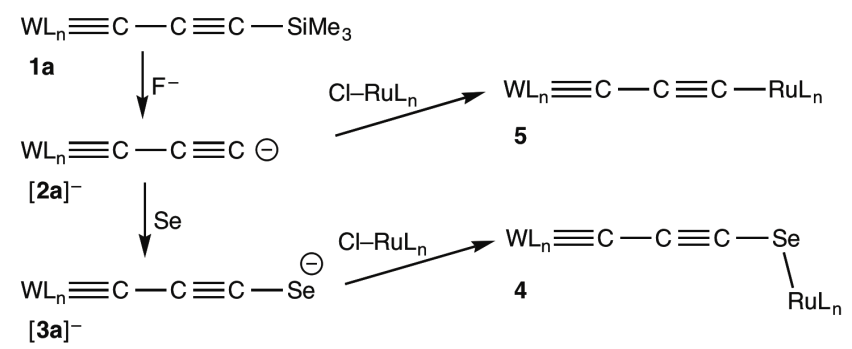

The molecular geometry of 4 (Figure 3 ) has an essentially linear ${ }^{18}$ WCCCSe spine with a C3-Se1-Rul angle of $\left.103.32(12)^{\circ}\right)$ consistent with conventional $s p^{3}$-hybridised selenium bound to $d^{6}$ pseudo-octahedral ruthenium which is not especially receptive to $\pi$ donor interactions. The bond lengths along the WCCC fall within the norms for $\mathrm{W} \equiv \mathrm{C}(s p), \mathrm{C}(s p)-\mathrm{C}(s p)$ and $\mathrm{C}(s p) \equiv \mathrm{C}(s p)$ separations consistent with the valence bond description chosen in Scheme 2. The geometries of the ' $\mathrm{W}(\mathrm{CO})_{2}(\mathrm{Tp})^{*}$ ' and ' $\mathrm{Ru}\left(\mathrm{PPh}_{3}\right)_{2}\left(\eta-\mathrm{C}_{5} \mathrm{H}_{5}\right)$ ' fragments are unremakable and conform to the copious structural data available for their complexes. ${ }^{17,19}$

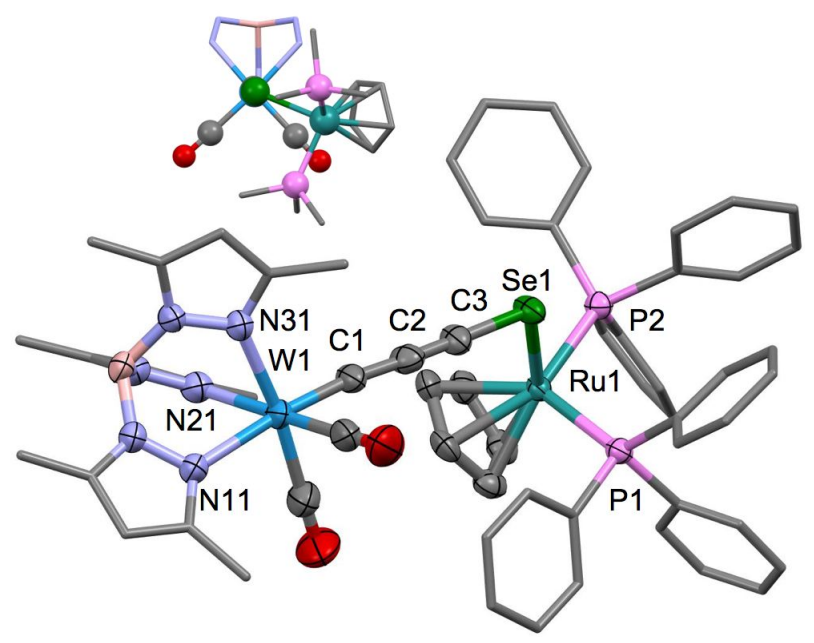

Figure 3. Molecular structure of 4 in a crystal $(70 \%$ displacement ellipsoids, hydrogen omitted for clarity, phenyl and pyrazolyl groups simplified). Selected bond lengths $(\AA)$ and angles $\left({ }^{\circ}\right)$ : W1C1 1.852(4), C1-C2 1.359(5), C2-C3 1.223(5), Se1-C3 1.810(4), Ru1-Se1 2.5164(5) Å, Ru1-P1 2.3409(10), Ru1-P2 2.3282(9), W1-C1-C2 174.3(2), C1-C2-C3 173.7(3), Se1-C3-C2 177.7(4), Ru1-Se1-C3 103.32(12).

As noted above, the yield of $\mathbf{4}$ was disappointing, in part due to losses during purification and also in part due to the formation of a second complex, identified as the bimetallic tricarbido complex
$\left[\mathrm{WRu}(\mu-\mathrm{CCC})(\mathrm{CO})_{2}\left(\mathrm{PPh}_{3}\right)_{2}\left(\eta-\mathrm{C}_{5} \mathrm{H}_{5}\right)\left(\mathrm{Tp}^{*}\right)\right]$ (5) which presumably arises due to the presence of either unreacted [2a $]^{-}$or the operation of an equilibrium between $[\mathbf{2 a}]^{-}$and $[\mathbf{3 a}]^{-}$. The identity of $\mathbf{5}$ was confirmed by a deliberate (selenium free) synthesis, spectroscopic data and a crystallographic study (Figure 4). The related complexes $\left[\mathrm{MRu}(\mu-\mathrm{CCC})(\mathrm{CO})_{2}(\mathrm{dppe})\left(\eta-\mathrm{C}_{5} \mathrm{Me}_{5}\right)\left(\mathrm{Tp}^{*}\right)\right](\mathrm{M}=\mathrm{Mo}, \mathrm{W})$ and $\left[\mathrm{WRu}(\mu-\mathrm{CCC})(\mathrm{CO})_{2}(\mathrm{dppe})\left(\eta-\mathrm{C}_{5} \mathrm{Me}_{5}\right)(\mathrm{Tp})\right]$ have been prepared previously by Bruce via $\mathrm{KF}$ mediated desilylation of $\mathbf{1}$ in the presence of $\left[\mathrm{RuCl}(\right.$ dppe $\left.)\left(\eta-\mathrm{C}_{5} \mathrm{Me}_{5}\right)\right] .{ }^{10}$ In a similar manner, treating 1a with $\mathrm{KF}$ in the presence of $\left[\mathrm{RuCl}\left(\mathrm{PPh}_{3}\right)_{2}\left(\eta-\mathrm{C}_{5} \mathrm{H}_{5}\right)\right]$ afforded 5 in $33 \%$ yield. The spectroscopic data for $\mathbf{5}$ are directly comparable to those for other tricarbido complexes, ${ }^{9,10}$ the features of most interest being the ${ }^{13} \mathrm{C}$ NMR data associated with the $\mathrm{WCaC} \beta C \gamma \mathrm{Ru}$ spine, i.e., $\mathrm{C} \alpha$ appears in the region for conventional carbynes $\left(253.8,{ }^{1} J_{\mathrm{WC}}=\right.$ 187.2) while those due to $C \beta$ and $C \gamma$ appear to higher field at 142.1 $\left({ }^{2} J_{\mathrm{WC}}=52.9\right)$ and $131.5\left({ }^{2} J_{\mathrm{CP}}=48.32 \mathrm{~Hz}\right)$, respectively.

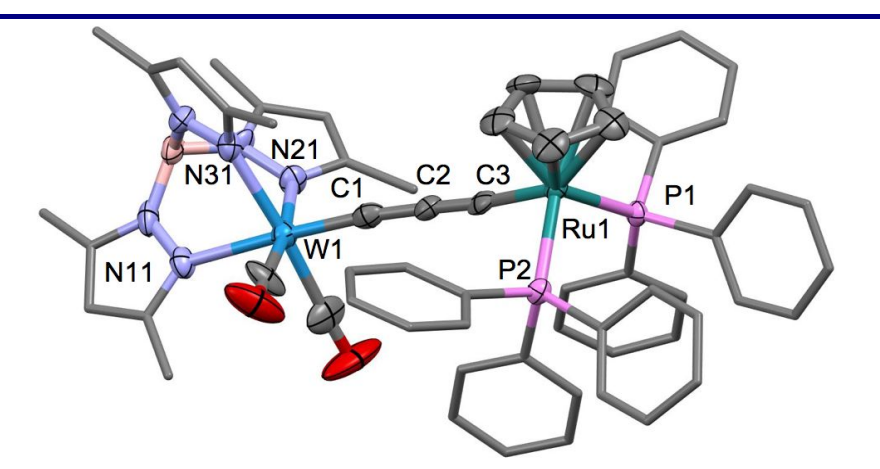

Figure 4. Molecular structure of $\mathbf{5}$ in a crystal $(70 \%$ displacement ellipsoids, hydrogen atoms omitted, phenyl and pyrazolyl groups simplified for clarity). Selected bond lengths $(\AA)$ and angles $\left(^{\circ}\right)$ : W1-C1 1.884(12), C1-C2 1.338(15), C2-C3 1.234(15), Ru1-C3 1.961(12) Å, Ru1-P1 2.305(2), Ru1-P2 2.297(3), W1-C1-C2 174.8(8), C1-C2-C3 173.7(3), Ru1-C3-C2 169.4(9).

Finally, a third complex $\mathbf{6}$ was isolated as a side product from the synthesis of $\mathbf{4}$ which was however only obtained in trace amounts, sufficient for crystallographic but not spectroscopic characterisation. The intriguing molecular structure is depicted in Figure 5 because it is without precedent. The yield was, however, too low to justify conjecture as to its mechanism of formation, though it is clearly composed of three parent propargylidyne "W( $\equiv \mathrm{CC} \equiv \mathrm{CH})(\mathrm{CO})_{2}\left(\mathrm{Tp}^{*}\right)$ " units. Accordingly, in the absence of evidence, a discussion of mechanistic possibilities is deferred to the Supporting Information.

\section{EXPERIMENTAL}

General Considerations. All manipulations of air-sensitive compounds were carried out under a dry and oxygen-free nitrogen atmosphere using standard Schlenk, vacuum line and inert atmosphere (argon) drybox techniques with dried and degassed solvents. NMR spectra were obtained at $25^{\circ} \mathrm{C}$ on Bruker AVANCE $400\left({ }^{1} \mathrm{H}\right.$ at $399.9 \mathrm{MHz},{ }^{31} \mathrm{P}$ at $\left.162.0 \mathrm{MHz}\right)$, AVANCE $600\left({ }^{1} \mathrm{H}\right.$ NMR at $600.0 \mathrm{MHz},{ }^{13} \mathrm{C}$ NMR at $150.9 \mathrm{MHz}$ ) or AVANCE 800 $\left({ }^{1} \mathrm{H} \mathrm{NMR}\right.$ at $800.1 \mathrm{MHz},{ }^{13} \mathrm{C} \mathrm{NMR}$ at $201.0 \mathrm{MHz}$ ) spectrometers. Chemical shifts $(\delta)$ are reported in ppm and referenced to the solvent peak $\left({ }^{1} \mathrm{H},{ }^{13} \mathrm{C}\right)$ or external reference $\left({ }^{31} \mathrm{P}, \mathrm{H}_{3} \mathrm{PO}_{4}\right)$ with coupling constants given in $\mathrm{Hz}$. Infrared spectra were obtained from 
solution and in the solid state (Nujol) using a Perkin-Elmer Spectrum One FT-IR spectrometer. Electrospray ionisation mass spectrometry (ESI-MS, low and high resolution) was performed by the ANU Research School of Chemistry mass spectrometry service with acetonitrile as the matrix. Elemental microanalytical data were provided by the Macquarie University Chemical Analysis Facility. Crystallographic data were collected with an Agilent Supernova diffractometer. The compounds $\left[\mathrm{W}\left(\equiv \mathrm{CC} \equiv \mathrm{CSiMe}_{3}\right)(\mathrm{CO})_{2}\left(\mathrm{Tp}^{*}\right)\right]^{13}$ and $\left[\mathrm{RuCl}\left(\mathrm{PPh}_{3}\right)_{2}\left(\eta-\mathrm{C}_{5} \mathrm{H}_{5}\right)\right]^{20}$ have been described previously. All other reagents were obtained from commercial sources. Reaction progress was typically monitored by in situ solution IR spectroscopy and thin layer chromatography (silica gel).

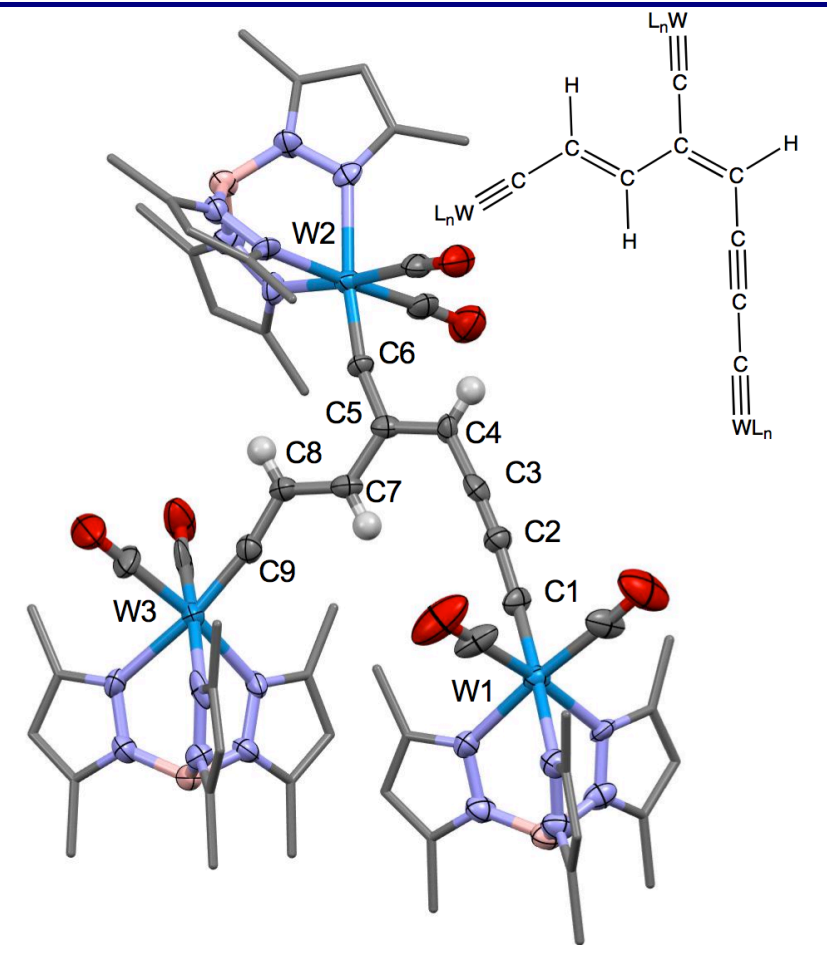

Figure 5. Molecular structure of $\mathbf{6}$ in a crystal of $\mathbf{6}\left(\mathrm{CHCl}_{3}\right)_{2}\left(\mathrm{C}_{6} \mathrm{H}_{14}\right)$ (70\% displacement ellipsoids, most hydrogen atoms omitted, phenyl and pyrazolyl groups simplified for clarity). Selected bond lengths (A): W1-C1 1.842(9), W2-C6 1.841(8), W3-C9 1.841(9), C1-C2 1.385(12), C2-C3 1.193(12), C3-C4 1.436(12), C4-C5 1.358(12), C5-C6 1.432(11), C5-C7 1.467(12), C7-C8 1.357(13), C8-C9 $1.420(12)$.

Computational details. All computational works were performed using the Gaussian $09^{\mathrm{TM}}$ suite of programs. The geometry of complex [2] was optimized at the DFT level of theory using the exchange functional of Becke ${ }^{21}$ in conjunction with the correlation functional of Perdew ${ }^{22}$ (BP86). The Stuttgart basis set in combination with the 60 -core-electron relativistic effective core potential (SDD) ${ }^{23}$ was used for $\mathrm{W} ; 6-31 \mathrm{G}(\mathrm{d})^{24}$ basis sets were used for all other atoms. Frequency calculations were performed to confirm that the optimized structure was minimal using the same level of theory. NBO calculations were performed using the NBO5 implementation within Gaussian 09 ${ }^{\mathrm{TM}} \cdot{ }^{25}$

Generation of $\left[{ }^{n} \mathrm{Bu}_{4} \mathrm{~N}\right]\left[\mathrm{W}(\mathrm{CCCSe})(\mathrm{CO})_{2}\left(\mathrm{Tp}^{*}\right)\right]\left[{ }^{n} \mathrm{Bu}_{4} \mathrm{~N}\right][3 \mathrm{a}]$. A mixture of $\left[\mathrm{W}\left(\equiv \mathrm{C}-\mathrm{C} \equiv \mathrm{C}-\mathrm{SiMe}_{3}\right)(\mathrm{CO})_{2}\left(\mathrm{Tp}^{*}\right)\right](\mathbf{1 a}: 100 \mathrm{mg}$, $0.157 \mathrm{mmol})$ and elemental grey selenium (13 mg, $0.16 \mathrm{mg}$.atom) in THF $(30 \mathrm{~mL})$ was treated with a solution of TBAF in THF $(0.16$ $\mathrm{mL}, 1.0 \mathrm{M}, 0.16 \mathrm{mmol}$ ) and left to stir for 20 minutes at room temperature to provide a dark brown solution. IR (THF, $\left.\mathrm{cm}^{-1}\right): v_{\mathrm{C} \equiv \mathrm{C}}$ $=1973 \mathrm{vs}, v_{\mathrm{CO}}=1898 \mathrm{vs}, 1833 \mathrm{vs}$. The solution thus formed shows little deterioration over 24 hours under strictly anaerobic conditions.

Synthesis of $\left[\mathrm{WRu}(\mu-\mathrm{CCCSe})(\mathrm{CO})_{2}\left(\mathrm{PPh}_{3}\right)_{2}\left(\mathrm{Tp}^{*}\right)\left(\eta-\mathrm{C}_{5} \mathrm{H}_{5}\right)\right]$ (4) A mixture of $\left[\mathrm{W}\left(\equiv \mathrm{C}-\mathrm{C} \equiv \mathrm{C}-\mathrm{SiMe}_{3}\right)(\mathrm{CO})_{2}\left(\mathrm{Tp}^{*}\right)\right](\mathbf{1 a}: 100 \mathrm{mg}$, $0.157 \mathrm{mmol})$ and elemental grey selenium (13 mg, $0.16 \mathrm{mg}$.atom) in THF $(30 \mathrm{~mL})$ was treated with a solution of TBAF in THF $(0.16$ $\mathrm{mL}, 1.0 \mathrm{M}, 0.16 \mathrm{mmol}$ ) and left to stir for 20 minutes at room temperature to provide a dark brown solution. A suspension of $\left[\mathrm{RuCl}\left(\mathrm{PPh}_{3}\right)_{2}\left(\eta-\mathrm{C}_{5} \mathrm{H}_{5}\right)\right](113 \mathrm{mg}, 0.16 \mathrm{mmol})$ in THF $(10 \mathrm{~mL})$ was added to the dark brown mixture which was stirred for a further 48 $\mathrm{h}$. The solvent was removed under reduced pressure to leave a dark brown solid. The resulting residue was extracted with dichloromethane, concentrated and chromatographed on a silica gel column, eluding with hexane/DCM (1:1). The orange band was collected and freed of volatiles under reduced pressure to provide 4 as an orange microcrystalline powder. Yield $13 \mathrm{mg}(6 \%)$. IR THF: $v_{\mathrm{CO}}=1941 \mathrm{vs}, 1866 \mathrm{vs} \mathrm{cm}^{-1}$. KBr: $v_{\mathrm{C} \equiv \mathrm{C}}=1994 \mathrm{w}, v_{\mathrm{CO}}=1973 \mathrm{vs}$, $1861 \mathrm{vs} \mathrm{cm}^{-1} .{ }^{1} \mathrm{H} \mathrm{NMR}\left(\mathrm{CDCl}_{3}, 25^{\circ} \mathrm{C}, 600.0 \mathrm{MHz}\right): \delta_{\mathrm{H}}=7.3-7.26$ $\left(\mathrm{m}, 30 \mathrm{H}, \mathrm{C}_{6} \mathrm{H}_{5}\right), 5.93(2 \mathrm{H}), 5.80(1 \mathrm{H})(\mathrm{s} \times 2,3 \mathrm{H}, \mathrm{pzH}), 4.40(5 \mathrm{H}$, $\left.\mathrm{C}_{5} \mathrm{H}_{5}\right) 2.71(6 \mathrm{H}), 2.52(3 \mathrm{H}), 2.45(6 \mathrm{H}), 2.39(3 \mathrm{H}),(\mathrm{s} \times 4,18 \mathrm{H}$, $\left.\mathrm{pzCH}_{3}\right) .{ }^{13} \mathrm{C}\left\{{ }^{1} \mathrm{H}\right\} \mathrm{NMR}\left(\mathrm{CDCl}_{3}, 25^{\circ} \mathrm{C}, 150.9 \mathrm{MHz}\right): \delta_{\mathrm{C}}=252.7(\mathrm{~W}$ $\left.\equiv \mathrm{C},{ }^{1} J_{\mathrm{WC}}=193.3\right), 227.4\left(\mathrm{WCO},{ }^{1} J_{\mathrm{WC}}=166.1\right), 152.5(\mathrm{pz}-\mathrm{C} 5)$, $152.3\left(\mathrm{pz}-\mathrm{C}^{5}\right), 144.7\left(\mathrm{pz}-\mathrm{C}^{3}\right), 144.0\left(\mathrm{pz}-\mathrm{C}^{3}\right), 138.6\left(\mathrm{C}_{6} \mathrm{H}_{5}\right), 133.8(\mathrm{t}$, $\left.J_{\mathrm{CP}}=9.1, \mathrm{C}_{6} \mathrm{H}_{5}\right), 129.1\left(\mathrm{C}_{6} \mathrm{H}_{5}\right), 127.8\left(\mathrm{t}, J_{\mathrm{CP}}=9.1, \mathrm{C}_{6} \mathrm{H}_{5}\right), 109.1$ $\left(\mathrm{C} \beta,{ }^{2} J_{\mathrm{WC}}=57.4\right), 106.4\left(\mathrm{pzC}^{4}\right), 106.8\left(\mathrm{pzC}^{4}\right), 84.7\left(\mathrm{C}_{5} \mathrm{H}_{5}\right), 83.83(\mathrm{t}$, $\left.\mathrm{C} \gamma,{ }^{3} J_{\mathrm{CP}}=10.6 \mathrm{~Hz},\right) 16.9\left(\mathrm{pzCH}_{3}\right), 15.5,\left(\mathrm{pzCH}_{3}\right), 12.8\left(\mathrm{pzCH}_{3}\right)$, $12.7\left(\mathrm{pzCH}_{3}\right) .{ }^{31} \mathrm{P}\left\{{ }^{1} \mathrm{H}\right\} \mathrm{NMR}\left(\mathrm{CDCl}_{3}, 25^{\circ} \mathrm{C}, 162.0 \mathrm{MHz}\right): \delta_{\mathrm{P}}=$ 47.76 $\left(\mathrm{PPh}_{3}\right)$. MS (ESI - high resolution): $m / z(\%) 1345.1908$. Calcd. for $\mathrm{C}_{61} \mathrm{H}_{58}{ }^{11} \mathrm{BN}_{6} \mathrm{O}_{2} \mathrm{P}_{2}{ }^{102} \mathrm{Ru}^{80} \mathrm{Se}^{184} \mathrm{~W}$ : 1345.1908 - $[\mathrm{HM}]^{+}$. Anal. Found: C, 54.81, 54.92; H, 4.82, 4.76; N, 5.98, 6.01\%. Calcd. for $\mathrm{C}_{61} \mathrm{H}_{57} \mathrm{BN}_{6} \mathrm{O}_{2} \mathrm{P}_{2} \mathrm{RuSeW}$ : C, 54.56; H, 4.28; N, 6.26\%. Crystals suitable for diffractometry were grown by slow diffusion of EtOH into a solution of the complex in THF. Crystal data: $\mathrm{C}_{61} \mathrm{H}_{57} \mathrm{BN}_{6} \mathrm{O}_{2} \mathrm{P}_{2} \mathrm{RuSeW}, M_{r}=1342.80, T=150(2) \mathrm{K}$, triclinic $P-1$ (No. 2), $a=12.8279(3), b=16.7190(4), c=17.7083(4) \AA, \alpha=$ 101.538(2), $\beta=105.856, \gamma=110.987(2)^{\circ}, V=3216.41(16) \AA^{3}, Z=$ 2, $D_{\text {calcd }}=1.386 \mathrm{Mg} \mathrm{m}^{-3}, \mu(\mathrm{Mo} \mathrm{K} \alpha) 2.68 \mathrm{~mm}^{-1}$, dark red plate, 0.34 $\times 0.23 \times 0.09 \mathrm{~mm}, 32466$ measured reflections with $2 \theta_{\max }=59.6^{\circ}$, 15213 independent reflections, 15154 adsorption-correct data used in $F^{2}$ refinement, 676 parameters, no restraints, $R_{1}=0.034, w R_{2}=$ 0.069 for 12063 reflections with $I>2 \sigma(I)$, CCDC 1034126 .

Synthesis of $\left[\mathrm{WRu}(\mu-\mathrm{CCC})(\mathrm{CO})_{2}\left(\mathrm{PPh}_{3}\right)_{2}\left(\mathrm{Tp}^{*}\right)\left(\eta-\mathrm{C}_{5} \mathrm{H}_{5}\right)\right]$ (5). A mixture of $\left[\mathrm{W}\left(\equiv \mathrm{C}-\mathrm{C} \equiv \mathrm{C}-\mathrm{SiMe}_{3}\right)(\mathrm{CO})_{2}\left(\mathrm{Tp}^{*}\right)\right]$ (1a: $400 \mathrm{mg}$, $0.620 \mathrm{mmol}),\left[\mathrm{RuCl}\left(\mathrm{PPh}_{3}\right)_{2}\left(\eta-\mathrm{C}_{5} \mathrm{H}_{5}\right)(452 \mathrm{mg}, 0.620 \mathrm{mmol})\right.$ and $\mathrm{KF}$ $(50 \mathrm{mg}, 0.81 \mathrm{mmol})$ in methanol $(100 \mathrm{~mL})$ was stirred for 48 hours at room temperature. The solvent was removed via cannula filtration to leave an orange solid. The orange solid was redissolved in the minimum amount of THF layered with ethanol and left to stand at room temperature for 24 hours to provide dark red microcrystals. The red crystals were washed with ethanol then washed with hexane and dried in vacuo to give compound $\mathbf{5}$ as red micro crystals. Yield: $261 \mathrm{mg}(33 \%)$. IR (THF): $v_{\mathrm{C} \equiv \mathrm{C}}=1980 \mathrm{~s}, v_{\mathrm{CO}}$ $=1905 \mathrm{vs}, 1845 \mathrm{vs} \mathrm{cm}^{-1} .{ }^{1} \mathrm{H}$ NMR $\left(\mathrm{CDCl}_{3}, 25^{\circ} \mathrm{C}, 600.0 \mathrm{MHz}\right): \delta_{\mathrm{H}}=$ $7.49-7.12\left(\mathrm{~m}, 30 \mathrm{H}, \mathrm{C}_{6} \mathrm{H}_{5}\right), 5.86(2 \mathrm{H}), 5.72(1 \mathrm{H})(\mathrm{s} \times 2,3 \mathrm{H}$, pzH), $4.34\left(\mathrm{~s}, 5 \mathrm{H}, \mathrm{C}_{5} \mathrm{H}_{5}\right), 2.68(6 \mathrm{H}), 2.48(3 \mathrm{H}), 2.37(6 \mathrm{H}), 2.32(3$ $\mathrm{H})\left(\mathrm{s} \times 4,18 \mathrm{H}, \mathrm{pzCH}_{3}\right) \cdot{ }^{13} \mathrm{C}\left\{{ }^{1} \mathrm{H}\right\}$ NMR $\left(\mathrm{CDCl}_{3}, 25^{\circ} \mathrm{C}, 150.9\right.$ $\mathrm{MHz}): \delta_{\mathrm{C}}=253.8\left(\mathrm{~W} \equiv \mathrm{C},{ }^{1} J_{\mathrm{WC}}=187.2\right), 228.1\left(\mathrm{WCO},{ }^{1} J_{\mathrm{WC}}=\right.$ 
169.1), $152.4\left(\mathrm{pz}-\mathrm{C}^{5}\right), 152.0\left(\mathrm{pz}-\mathrm{C}^{5}\right), 144.2\left(\mathrm{pz}-\mathrm{C}^{3}\right), 143.7\left(\mathrm{pz}-\mathrm{C}^{3}\right)$, $142.1\left(\mathrm{C} \beta,{ }^{2} J_{\mathrm{WC}}=52.9\right), 137.9\left(\mathrm{C}_{6} \mathrm{H}_{5}\right), 133.8\left(\mathrm{t}, J_{\mathrm{CP}}=9.06, \mathrm{C}_{6} \mathrm{H}_{5}\right)$ $131.5\left(\mathrm{t}, \mathrm{C} \gamma,{ }^{2} J_{\mathrm{CP}}=48.3\right), 128.9\left(\mathrm{C}_{6} \mathrm{H}_{5}\right), 127.6\left(\mathrm{t}, J_{\mathrm{CP}}=9.06, \mathrm{C}_{6} \mathrm{H}_{5}\right)$ 106.1 (pz-C $\left.{ }^{4}\right), 86.7\left(\mathrm{C}_{5} \mathrm{H}_{5}\right), 16.7\left(\mathrm{pz}-\mathrm{CH}_{3}\right), 15.6,\left(\mathrm{pz}^{-} \mathrm{CH}_{3}\right), 12.8$ (pz$\left.\mathrm{CH}_{3}\right), 12.7\left(\mathrm{pz}-\mathrm{CH}_{3}\right) .{ }^{31} \mathrm{P}\left\{{ }^{1} \mathrm{H}\right\} \mathrm{NMR}\left(\mathrm{CDCl}_{3}, 25^{\circ} \mathrm{C}, 162.0 \mathrm{MHz}\right): \delta_{\mathrm{P}}$ $=47.76\left(\mathrm{PPh}_{3}\right)$. MS (ESI- high resolution): $\mathrm{m} / z(\%) 1264.2664$. Calcd. for $\mathrm{C}_{61} \mathrm{H}_{57}{ }^{11} \mathrm{BN}_{6} \mathrm{O}_{2} \mathrm{P}_{2}{ }^{102} \mathrm{Ru}^{184} \mathrm{~W}$ : $1264.2664[\mathrm{M}]^{+}$. Anal. Found: C, 57.83, 57.86; H, 4.65, 4.68; N, 6.61, 6.63\% Calcd. for $\mathrm{C}_{61} \mathrm{H}_{57} \mathrm{BN}_{6} \mathrm{O}_{2} \mathrm{P}_{2} \mathrm{RuW}: \mathrm{C}, 57.97 ; \mathrm{H}, 4.55 ; \mathrm{N}, 6.65 \%$. Crystals suitable for diffractometry were grown by slow diffusion of EtOH into a solution of the complex in THF. Crystal data: $\mathrm{C}_{61} \mathrm{H}_{57} \mathrm{BN}_{6} \mathrm{O}_{2} \mathrm{P}_{2} \mathrm{RuW}, M r=1263.84, T=150(2) \mathrm{K}$, monoclinic, space group $P 2_{1} / c, a=19.5256(4), b=11.5909(2), c=25.6190(5)$ $\AA, \beta=110.124(2)^{\circ}, V=5444.10(19) \AA^{3}, Z=4, D_{\text {calcd }}=1.542 \mathrm{Mg}$ $\mathrm{m}^{-3}, \mu(\mathrm{Cu} \mathrm{K} \alpha) 7.04 \mathrm{~mm}^{-1}$, orange prism, $0.10 \times 0.03 \times 0.02 \mathrm{~mm}$, 34926 measured reflections with $2 \theta_{\max }=144.4^{\circ}, 10641$ independent reflections, 10628 adsorption-corrected data used in $F^{2}$ refinement, 667 parameters, 30 restraints, $R_{1}=0.074, w R_{2}=0.170$ for 9485 reflections with $I>2 \sigma(I)$, CCDC 1034124 .

$\begin{array}{lrrr}\text { Crystal Structure } & \text { Determination of } & \text { Compound } \\ \text { 6. }\left(\mathrm{CHCl}_{3}\right)_{2}\left(\mathbf{C}_{6} \mathbf{H}_{14}\right) \text {. } & \text { Crystal } & \text { data: }\end{array}$
$\mathrm{C}_{60} \mathrm{H}_{69} \mathrm{~B}_{3} \mathrm{~N}_{18} \mathrm{O}_{6} \mathrm{~W}_{3} .2\left(\mathrm{CHCl}_{3}\right) \cdot \mathrm{C}_{6} \mathrm{H}_{14}, M r=2047.24, T=150(2) \mathrm{K}$, monoclinic, space group $P 2{ }_{1} / c, a=28.4915(6), b=14.3502(2), c=$ $21.8360(5) \AA, \beta=105.233(2)^{\circ}, V=8614.2(3) \AA^{3}, Z=4, D_{\text {calcd }}=$ $1.578 \mathrm{Mg} \mathrm{m}^{-3}, \mu(\mathrm{Mo} \mathrm{K} \alpha) 4.24 \mathrm{~mm}^{-1}$, dark red block, $0.09 \times 0.15 \times$ $0.24 \mathrm{~mm}, 21391$ measured reflections with $2 \theta_{\max }=60.0^{\circ}, 21303$ independent reflections, 21303 adsorption-corrected data used in $F^{2}$ refinement, 937 parameters, 43 restraints, $R_{1}=0.0715, w R_{2}=0.123$ for 17805 reflections with $I>2 \sigma(I)$, CCDC 1034125 .

\section{- CONCLUSIONS}

In summary, we have isolated the first example of a bimetallic complex bridged by the selenoxypropadienylidene CCCSe group and provided evidence for the intermediacy of a terminal complex [3a] $]^{-}$of this ligand. The synthetic approach appreciates similarities between the behaviour of alkynylselenolate and selenocarbonylate nucleophiles towards metal halides by extending the principle to $[\mathbf{3 a}]^{-}$. The complex 4 joins a range of isoselenocarbonyl ${ }^{7}$ and isothiocarbonyl complexes ${ }^{25}$ and the recently reported thioxoethenylidene complex $\left[\mathrm{Mo}_{2}(\mu-\mathrm{CCS})(\mathrm{CO})_{4}\left(\mathrm{Tp}^{*}\right)_{2}\right]^{26}$ in demonstrating the viability of bimetallics linked by linear carbon chalcogenide chains.

\section{ASSOCIATED CONTENT}

\section{S Supporting Information}

Crystallographic data for 4 (CCDC 1034126), 5 (CCDC 1034124) and 6 (CCDC 1034125) in CIF format; Cartesian coordinates for optimised geometries of $\mathrm{C}_{3} \mathrm{O}, \mathrm{C}_{3} \mathrm{~S}, \mathrm{C}_{3} \mathrm{Se}$ and [3a] $]^{-}$in .xyz format; Mechanistic conjecture on the formation of $\mathbf{6}$. This information is available free of charge via the internet at http://pubs.acs.org.

\section{- AUTHOR INFORMATION Corresponding Author}

*Email: a.hill@anu.edu.au (A.F.H)

\section{Notes}

The authors declare no competing financial interest.

\section{ACKNOWLEDGEMENTS}

This work was supported by the Australian Research Council (DP130102598 and DP110101611). This research was undertaken with the assistance of resources provided at the NCI National Facility systems at the Australian National University through the National Computational Merit Allocation Scheme supported by the Australian Government and the Tasmanian Partnership for Advanced Computing. MS acknowledges the University of Tasmania for an Honourary Associateship.

\section{REFERENCES}

(1) Wang, H.-Y.; Huang, R.-B.; Chen, H.; Lin, M.-H.; Zheng, L.-S. J. Phys. Chem. A. 2001, 105, 4653.

(2) Reddy, P. N.; Srikanth, R.; Swamy, N. S.; Bhanuprakash, K.; Srinivas, R. Int. J. Mass Spec. 2004, 232, 231.

(3) Bundhun, A.; Ramasami, P. Eur. Phys. J. D. 2010, 57, 355.

(4) Caldwell, L. M.; Hill, A. F.; Hulkes, A. G.; McQueen, C. M. A.; White, A. J. P.; Williams, D. J. Organometallics 2010, 29, 6350. (b) Bedford, R. B.; Dyson, P. J.; Hill, A. F.; Hulkes, A. G.; Yates, C. J. Organometallics 1998, 17, 4117. (c) Baxter, I.; Hill, A. F.; Malget, J. M.; White, A. J. P.; Williams, D. J. J. Chem. Soc., Chem. Commun. 1997, 2049.

(5) (a) Weigand, W. Z. Naturforsch., B 1991, 46, 1333. (b) Weigand, W.; Robl, C. Chem. Ber. 1993, 126, 1807. (c) Weigand, W.; Weishaupl, M.; Robl, C. Z. Naturforsch., B 1996, 51, 501. (d) Cerrada, E.; Laguna, M.; Lardies, N. Eur. J. Inorg. Chem. 2009, 137. (e) Lardies, N.; Romeo, I.; Cerrada, E.; Laguna, M.; Skabara, P. J. Dalton Trans. 2007, 5329. (f) Delgado, E.; Hernandez, E.; Menacho, M.; Munoz, R. Inorg. Chem. Commun. 2006, 9, 139. (g) Delgado, E.; Donnadieu, B.; Garcia, S.; Zamora, F. J. Organomet. Chem. 2002, 649, 21. (h) Ara, I.; Delgado, E.; Fornies, J.; Hernandez, E.; Lalinde, E.; Mansilla, N.; Moreno, M. T. J. Chem. Soc., Dalton Trans. 1998, 3199. (i) Beswick, M. A.; Raithby, P. R.; Steiner, A.; Vallat, J. C.; Verhorevoot, K. L.; Wright, D. S. J. Chem. Soc., Dalton Trans. 1996, 2183. (j) Beswick, M. A.; Harmer, C. N.; Raithby, P. R.; Steiner, A.; Tombul, M.; Wright, D. S. J. Organomet. Chem. 1999, 573, 267. (k) Sunada, Y.; Hayashi, Y.; Kawaguchi, H.; Tatsumi, K. Inorg. Chem. 2001, 40, 7072. (1) Sugiyama, H.; Hayashi, Y.; Kawaguchi, H.; Tatsumi, K. Inorg. Chem. 1998, 37, 6773. (m) Schaefer, S.; Moser, C.; Tirree, J. J.; Nieger, M.; Pietschnig, R. Inorg. Chem. 2005, 44, 2798. (n) Pietschnig, R.; Merz, K.; Schaefer, S. Heteroat. Chem. 2005, 16, 169.

(6) Cordiner, R. L.; Hill, A. F.; Wagler, J. Organometallics 2008, 27, 5177.

(7) (a) Cade, I. A.; Hill, A. F.; McQueen, C. M. A. Organometallics 2009, 28, 6639. (b) Hill, A. F.; McQueen, C. M. A. Organometallics 2012, 31, 2482. (c) Caldwell, L. M.; Cordiner, R. L.; Hill, A. F.; Wagler, J. Organometallics 2010, 29, 1526.

(8) Caldwell, L. M.; Hill, A. F.; Wagler, J.; Willis, A. C. Dalton Trans. 2008, 3538 .

(9) (a) Dewhurst, R. D.; Hill, A. F.; Smith, M. K. Angew. Chem., Int. Ed. Engl. 2004, 43, 476; (b) Dewhurst, R. D.; Hill, A. F.; Willis, A. C. Organometallics 2004, 23, 5903. (c) Dewhurst, R. D.; Hill, A. F.; Willis, A. C. Organometallics, 2004, 23, 1646. (d) Dewhurst, R. D.; Hill, A. F.; Willis, A. C. Chem. Commun. 2004, 2826. (e) Dewhurst, R. D.; Hill, A. F.; Smith, M. K. Organometallics 2005, 24, 5576. (f) Dewhurst, R. D.; Hill, A. F.; Rae, A. D.; Willis, A. C. Organometallics 2005, 24, 4703. (g) Dewhurst, R. D.; Hill, A. F.; Smith, M. K. Organometallics 2005, 24, 6295. (h) Dewhurst, R. D.; Hill, A. F.; Willis, A. C. Organometallics 2005, 24, 3043. (i) Dewhurst, R. D.; Hill, A. F.; Willis, A. C. Dalton Trans. 2009, 3384.

(10) Bruce, M. I.; Cole, M. L.; Gaudio, M.; Skelton, B. W.; White, A. H. J. Organomet. Chem. 2006, 691, 4601 .

(11) (a) Weng, J. A. Ramsden, Arif, A. M. ; Gladysz, J. A. J. Am. Chem. Soc. 1993, 115, 3824; (b) Bartik, T.; Weng, W.; Ramsden, J. A.; 
Szafert, S.; Falloon, S. B.; Arif, A. M.; Gladysz, J. A. J. Am. Chem. Soc. 1998, 120, 11071; (c) Deminski, R.; Szafert, S.; Haquette, P.; Lis, T.; Gladysz, J. A. Organometallics 1999, 18, 5438.

(12) (a) Woodworth, B. E.; Templeton, J. L. J. Am. Chem. Soc. 1996, 118, 7418.

(13) The complexes $\mathbf{1}$ are readily available via Fischer's modification of the procedures developed for the complexes $\left[\mathrm{M}\left(\equiv \mathrm{CC} \equiv \mathrm{CCMe}_{3}\right)(\mathrm{CO})_{2} \mathrm{~L}\right](\mathrm{M}=\mathrm{Mo}, \mathrm{W}):{ }^{14}$ (a) Schwenzer, B.; Schleu, J.; Burzlaff, N.; Karl, C.; Fischer, H. J. Organomet. Chem. 2002, 641, 134; (b) Schwenzer, B.; Fischer, H. J. Organomet. Chem. 2003, 667, 16.

(14) Hart, I. J.; Hill, A. F.; Stone, F. G. A. J. Chem. Soc., Dalton Trans. 1989, 2261

(15)Enriquez, A. E; White, P. S; Templeton, J. L. J. Am. Chem. Soc. 2001, $123,4992$.

(16) Colebatch, A. L.; Hill, A. F. submitted to J. Am. Chem. Soc.

(17) Caldwell, L. M. Adv. Organomet. Chem. 2008, 56, 1.

(18) Angles at carbon for carbyne ligands have been observed to be as small as $163^{\circ}$ and such deformations are generally attributed to crystal packing effects. ${ }^{8,17}$

(19) (a) Conquest ${ }^{\circledR} 2014$ Release, Cambridge Crystallographic Data Center. (b) Structural data for 42 complexes of the form $\left[\mathrm{M}(\equiv \mathrm{CR})(\mathrm{CO})_{2}(\mathrm{~L})\right](\mathrm{L}=\mathrm{Tp}, \mathrm{Tp} * ; \mathrm{M}=\mathrm{Cr}, \mathrm{Mo}, \mathrm{W})$ are tabulated and discussed in reference 17. Recurrent features include an essentially octahedral coordination about tungsten in which the alkylidyne ligand exerts a pronounced trans influence on the pyrazolyl group to which it is trans disposed, relative to those trans to carbonyl ligands.

(20) Bruce, M. I; Windsor, N. J. Aust. J. Chem. 1977, 30, 1601.

(21) Becke, A. D. Phys. Rev. A 1998, 38, 3098.

(22) (a) Perdew, J. P. Phys. ReV. B 1986, 34, 7406. (b) Perdew, J. P. Phys. Rev. $B$ 1986, 33, 8822 .

(23) (a) Kuechle, W.; Dolg, M.; Stoll, H.; Preuss, H. J. Chem. Phys. 1994,100, 7535. (b) Dolg, M.; Stoll, H.; Preuss, H.; Pitzer, R. M. J. Phys. Chem. 1993,97, 5852.

(24) Hariharan, P. C.; Pople, J. A. Theor. Chim. Acta 1973, 28, 213.

(25) (a) Dombek, B. D.; Angelici, R. J. Inorg. Chem. 1976, 15, 2397. (b) Doyle, R. A.; Angelici, R. J. Organometallics 1989, 8, 2207. (c) Doyle, R.A.; Daniels, L. M.; Angelici, R. J. J. Am. Chem. Soc. 1989, 111, 4995. (d) Doyle, R.A.; Daniels, L. M.; Angelici, R. J. J. Am. Chem. Soc. 1989, 111, 4995.

(26) Caldwell, L. M.; Hill, A. F.; Stranger, R.; Terrett, R. N. L.; von Nessi, K. M.; Ward, J. S.; Willis, A. C. submitted to Organometallics. 


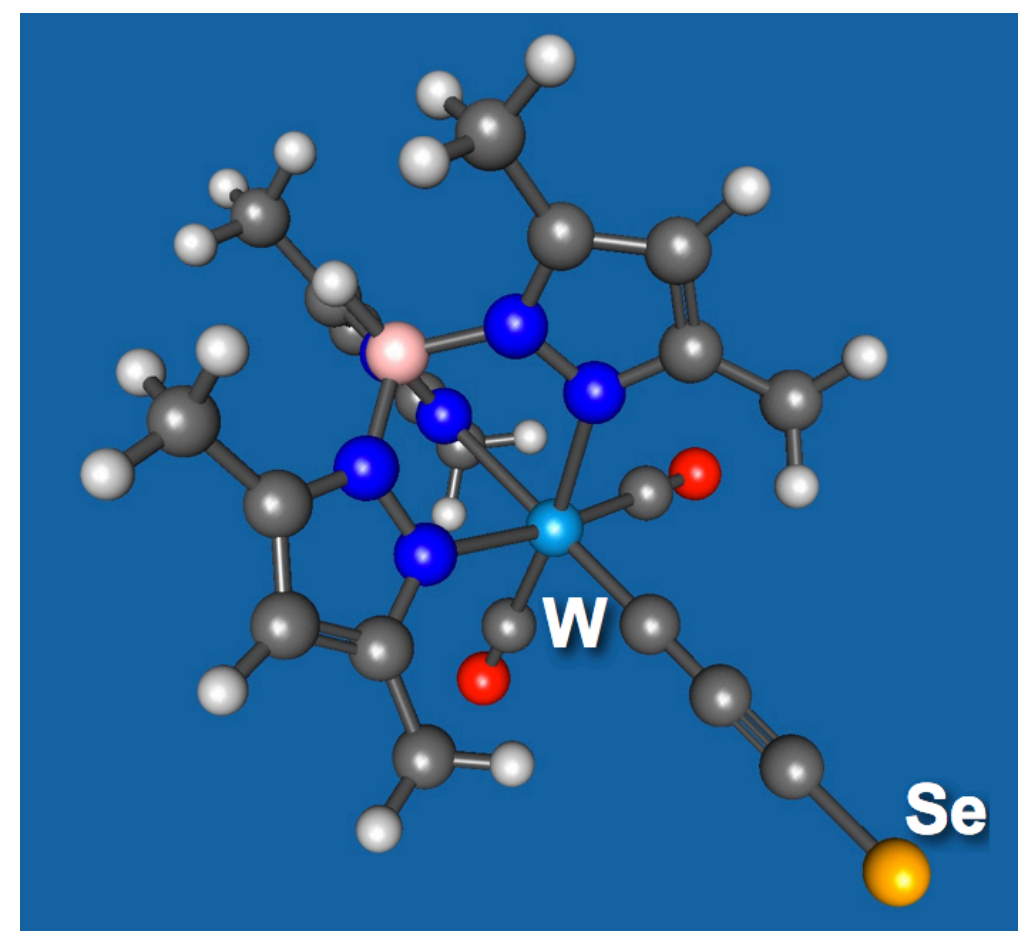

Insert Table of Contents artwork here 